Wisam M Al-Saeed

BVMS, MSc, PhD (Asst. Prof.)

Hind J Mahmood

BSc (Asst.Prof.)

\section{Effect of Maggot (larva) Secretions on Bacterial Growth}

\author{
Department of Dental Basic Science \\ College of Dentistry, University of Mosul
}

Mosul Technical Institute

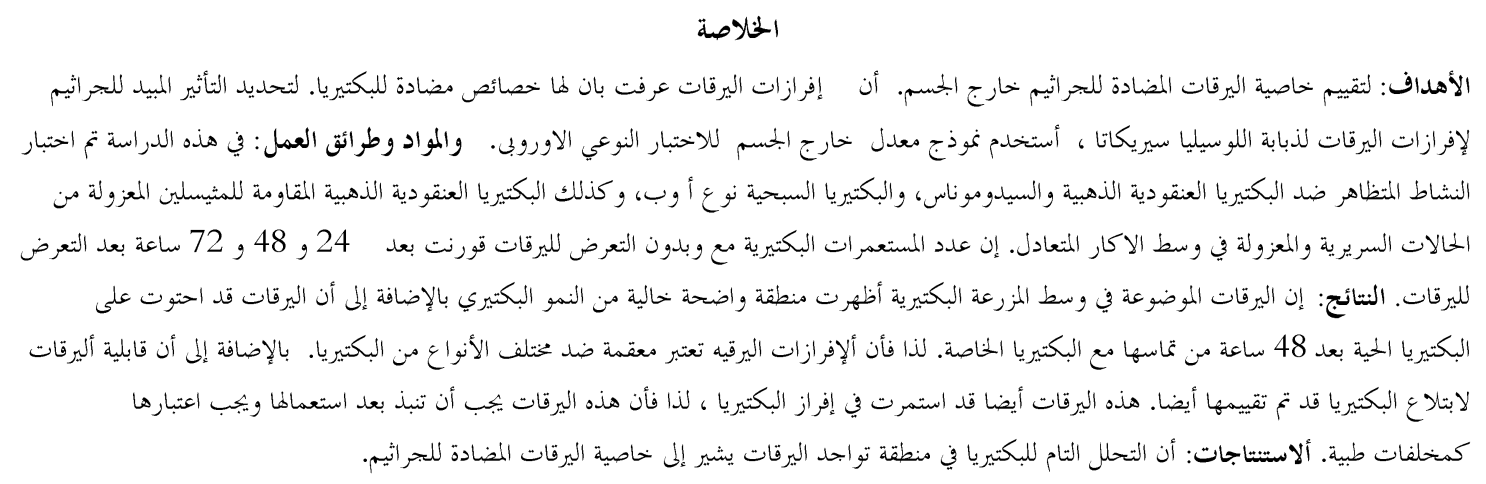

ABSTRACT

Aim: To evaluate the antimicrobial properties of maggots in- vitro. The secretions of maggots are known to have antibacterial properties. To quantify the bactericidal effect of secretions from larvae of L. sericata, an in vitro test model based on the modified European qualitative test. Material and method: In this study, the activity of the maggots was demonstrated against Staphylococcus aureus, Pseudomonas aeruginosa, Streptococcus group A and group B, and a clinical isolate of MRSA. The numbers of bacterial colonies with and without maggot exposure were compared after 24,48 and $72 \mathrm{~h}$ of exposure. Results: Maggots applied in the center of the bacterial culture showed a clear zone of inhibition of the bacterial growth in addition the maggot contained viable bacteria after $48 \mathrm{hrs}$ of contact with the respective organisms. Thus, the maggot secretions regarded as an antiseptic against different types of bacteria. In addition, the maggots ability to ingest bacteria was also evaluated. These maggots also continued excreting bacteria. Therefore, maggots should be disposed after use, as they must be regarded as medical wastes. Conclusions: Complete lyses of the bacteria in the area of maggots application indicated the antimicrobial properties of maggots.

Key words: Maggot, antimicrobial secretions, larva secretion

Al-Saeed WM, Mahmood HJ . Effect of Maggot (larva) Secretions on Bacterial Growth. $A l-$ Rafidain Dent J. 2012; 12(1): 160-164.

Received: 29/12/2010 Sent to Referees: $29 / 12 / 2010$ Accepted for Publication: 10/2/2011

\section{INTRODUCTION}

Live maggots were clinically suggested to kill or inhibit the growth of a wide range of pathogenic bacteria, especially Methicillin resistant Staphylococcus aureus (MRSA), group A and B Streptococci and Pseudomonas aeruginosa. ${ }^{(1,2,3,4)}$ They showed clinical activity against Pseudomonas species, although no formal prospective experimental study was arranged in the past. ${ }^{(1)}$ The use of maggots for the treatment of wounds has three beneficial effects: Debridement of necrotic tissue, promotion of tissue granulation, and wound-antisepsis due to antibacterial secretions. ${ }^{(5)}$ The presence of an antibacterial substance in the body and secretions of Lucilia sericata was demonstrated by Kerridge et $a l,{ }^{(6)}$ Furthermore, the destruction of ingested bacteria in the intestinal tract of the maggots was demonstrated by Mumcuoglu et al. ${ }^{(7)}$ In recent years, several reports have described the presence of two specific peptides with antibacterial activity, either in the body or the secretions of maggots - one peptide with a molecular weight of $2-10 \mathrm{kDa}$, and the other with a molecular weight of less than 1 
$\mathrm{kDa}{ }^{(3,6,8)}$ The objective of this work is to study the bactericidal activity of $L$. sericata maggot secretions on different types of bacteria and assessment of antiseptic compounds, as well as to evaluate their abilities to ingest bacteria.

\section{MATERIALS AND METHODS}

Lucillia sericata ( Green-bottle flies) family: Calliphoridae (9) are readily

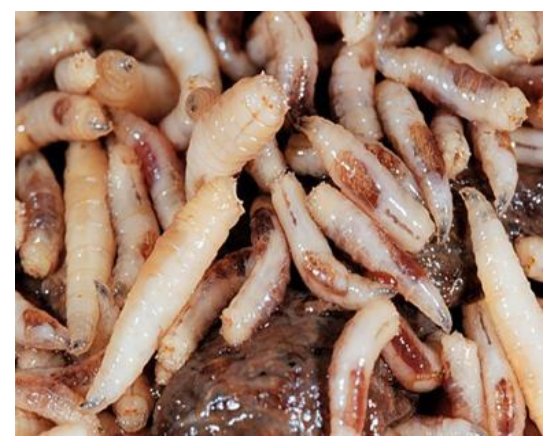

The hatching maggot (larvae) were then transferred to sterile vials. The collected sterile maggots kept for $24 \mathrm{hrs}$ on Columbia agar until they reached the third larval stage before being used for the experiments. Bacteria used in this study included methicillin- resistant $S$. aueaus (MRSA), isolated from a patient with an infected chronic wound, Streptococcus group A and B isolated from nasopharyngeal region and tonsils and Pseudomonas aerogenosa.typically found in wound infections. Application of live maggots, larvae of Lucilia (Phaenicia) sericata to total of 48 hour culture plates of Methicillin resistant Staphyloccocus aureus (MRSA), Pseudomonas aeruginosa, (12 plates in each group). The maggots were covered by a small plate inside the big plate with the pathogen. All plates were incubated in the standard incubator and examined 24,

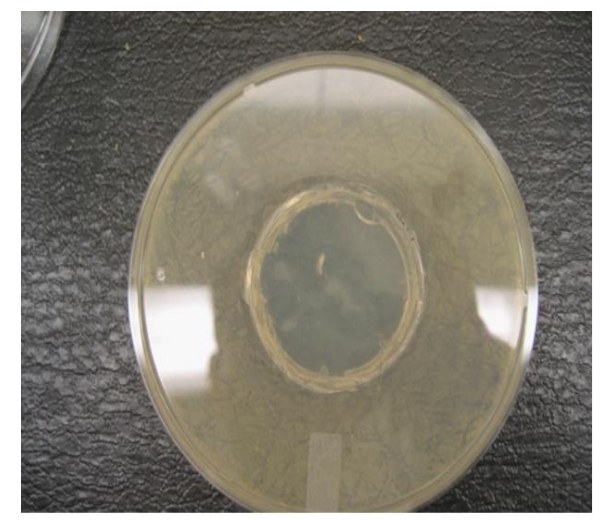

caught from the environment using $1 \mathrm{x} 1$ foot cage houses $>50$ flies, which live on water, dry sugar, and occasional meat. Every 3 days, eggs were collected from the underside of meat. Clusters were separated in $0.5 \%$ sodium hypochlorite, sterilized in $1 \%$ Lysol for 5 minutes, and hatch on chicken liver (Figure 1).

Figure 1: Maggots (Larvae) of Lucilia sericata (green bottle fly) on chiken liver.

48 and 72 hours after application of maggots. Degree of lyses in bacterial cultures in the area of maggot application (at the center of the cultured plate were estimated and Gram staining of both areas (centre \& periphery of the bacterial culture) was performed. Grams stain of smears made from the hemolymph and guts of the maggots were done to detect if any bacteria present after maggot use.

\section{RESULTS}

Complete lyses of the bacterial culture in the area of maggot application was observed after 24, 48, and 72 hours after application of live maggots in all culture plates of the different types of bacteria used in the experiment and confirmed by Gram staining (Figures: 2, 3, 4).

Figure (2): Maggot in the center of cillin resistant Staphylococcus. aureus (MRSA). Showing the central inhibition zone. 


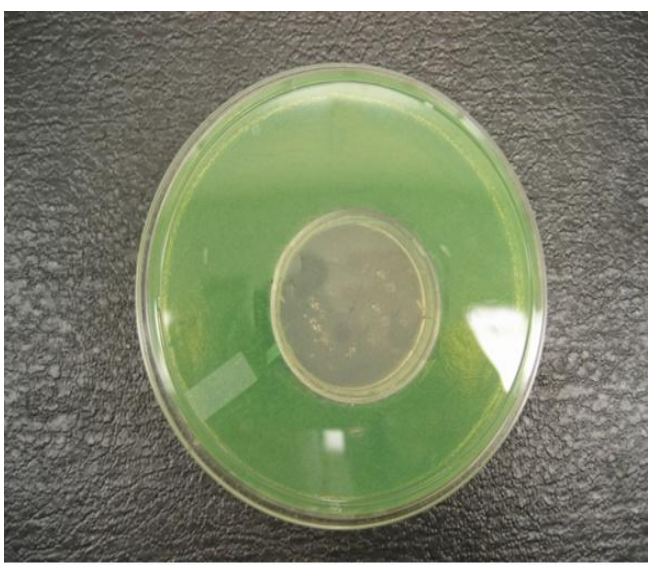

Figure (3): Maggot applied in culture of Pseudomonas aerugenosa \& clear zone of inhibition in the center of the culture (area of maggot application).

This complete lysis was persistent for more than 5 days after the maggot application. Grams staining of hemolymph and gut revealed no bacteria in the hemolymph and hind gut of larvae, but a good amount of bacteria was seen in the foregut and mid gut, where as the hindgut was free from any type of bacteria. Culturing of the contents of the fore \& mid gut revealed growth of bacteria after 24 hours of incubation, but no bacterial growth detected in culturing material from hindgut. This confirmed that the secretions of hindgut have specificity of antimicrobial substance.

\section{DISCUSSION}

Combating of wound infection by maggots is not entirely clear and several explanations have been suggested. In this study, the bactericidal activity of maggots was effective against all tested bacteria. This is in agreement with in vitro findings on the antibacterial effect of maggot secretion on E. coli , M. luteus , P. aeruginosa, Salmonella spp ., MSSA, MRSA, S. epidermidis and Listeria spp. ${ }^{(1)}$ Ammonia in maggot secretions may partly account for this antimicrobial effect by raising wound $\mathrm{pH}$. One report suggested that phenyl acetate and phenyl acetaldehyde may exert antimicrobial effect. Direct ingestion of bacteria along with semi liquid food by the maggots and subsequent lyses in their gut is also possible explanation. How maggots combat clinical infection in wounds has

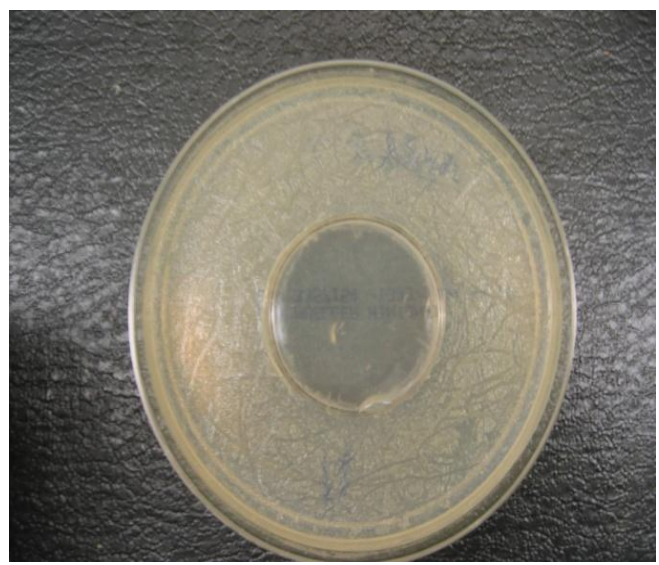

Figure (4): Streptococcus spp. Culture, the central inhibition zone is the area of maggot application.

been studied intensely over the years. Several mechanisms have been suggested, including simple mechanical irrigation of the wound by increased exudates, the production of which is stimulated by larvae ingesting liquefied necrotic tissue, or by dilution of wound discharge following wound lavage by the maggots' own secretions/excretions. ${ }^{(4,5)}$ The excretion of a waste product, ammonia, by Lucilia sericata was also believed to be responsible for combating bacterial infections, since ammonia increases wound $\mathrm{pH}$, resulting in alkaline conditions unfavorable to many bacterial species. ${ }^{(6,7)}$ In addition, larvae of L. sericata carry in their midgut a commensal, Proteus mirabilis. These commensals produce agents such as phenyl acetic acid (PAA) and phenyl acetaldehyde (PAL), with known antibacterial properties. ${ }^{(8)}$ The $\mathrm{pH}$ of maggot secretions is known to be between $8-8.5{ }^{(10-12)}$ Friedman et al., (1998), revealed that at alkaline $\mathrm{pH}$ the antibacterial potential of PAA is low, while PAL is unstable and therefore limited as a bactericide. ${ }^{(13)}$ A more likely explanation of how maggots combat wound infection is that larvae ingest wound bacteria, which are killed as they pass through the maggot's digestive tract, such destruction of ingested microbes was reported by Mumcuoglu, ${ }^{(7)}$ who noted that while the stomach and crop were heavily contaminated with viable bacteria the hindgut was sterile. ${ }^{(14)}$ The clinical find- 
ings are consistent with the observations that maggots can combat infections in a variety of wound types, including those infected with antibiotic-resistant strains. ${ }^{(5,}$ 11, 15) In fact, the treatment of wounds infected with MRSA is likely to become a major indication for the use of maggot therapy in the future. ${ }^{(3,4,16)}$ More recently, using high-performance liquid chromatography, an antibacterial agent from maggots was partially purified using Micrococcus luteus as the indicator bacteria. ${ }^{(14,}$ ${ }^{17)}$ This factor, reported to possess a molecular weight of $6000 \mathrm{Da}$, was digested by proteases, caused efflux of potassium ions from bacterial cells, and exhibited a wide spectrum of antibacterial activity against many resident pathogenic strains including MRSA. $^{(3,4,18)}$

\section{CONCLUSIONS}

Complete lyses of the bacterial cultures in the area of maggot application provides convincing evidence for the antimicrobial properties of maggots. The exact mechanism of antimicrobial property of maggots requires further investigation.

\section{REFERENCES}

1. Thomas S, Andrews A, Hay P, Bourgoise S. The anti-microbial activity of maggot secretions: results of a preliminary study. J Tissue Viability. 1999; 9:127-32.

2. Jarvis A. Maggot therapy. Lancet. 2000 Dec 9; 356(9246): 2016.

3. Bexfield A, Nigam Y, Thomas S, Ratcliffe NA. Detection and partial characterization of two antibacterial factors from the excretions/ secretions of the medicinal maggot Lucilia sericata and their activity against methicillinresistant Staphylococcus aureus (MRSA). Microbes Infect. 2004; 6: 1297-1304.

4. Dissemond J, Koppermann M, Esser S, Schultewolter T, Goos M, Wagner SN. Treatment of methicillin-resistant Staphylococcus aureus (MRSA) as part of biosurgical management of a chronic leg ulcer. Hautarzt. 2002 Sep; 53(9): 608-1.

5. Fleischmann W, Grassberger M, Sherman R. Maggot Therapy: A Handbook of Maggot- Assisted Wound Healing. Stuttgart, Georg Thieme, 2004.

6. Kerridge A, Lappin-Scott H, Stevens JR. Antibacterial properties of larval secretions of the blowfly, Lucilia sericata . Med. Vet. Entomol. 2005; 19: 333-337.

7. Mumcuoglu KY, Miller J, Mumcuoglu $\mathrm{M}$, et al.Destruction of bacteria in the digestive tract of the maggot of Lucilia sericata (Diptera: Calliphoridae). $J$ Med. Entomol. 2001; 38: 162-166.

8. Huberman L, Mumcuoglu KY, Gollop N, Galun R: Antibacterial substances excreted by the maggot of the green bottle fly, Lucilia sericata. Sixth interernational Conference on Biotherapy, Cumhuriyet University, Sivas, Turkey, 2003, pp 27-28.

9. Richard, W. \& Davies S. 2001. Veterinary ectoparasites: Biology, Pathology, and Control. 2nd edition, Blackwell Science Ltd. London England.

10. Wayman J, Nirojogi V, Walker A, Sowinski A, Walker MA. The cost effectiveness of larval therapy in venous ulcers. J Tissue Viability. 2000 Jul;10(3):91-4. Erratum in: J Tissue Viability 2001. Jan;11(1):51.

11.Bonn D. Maggot therapy: an alternative for wound infection. Lancet. 2000 Sep 30; 356(9236): 1174.

12.Vizioli J, Salzet M. Antimicrobial peptides from animals: focus on invertebrates. Trends Pharmacol Sci. 2002; 23: 494-6.

13. Friedman E, Shaharabany M, Ravin S, Golomb E, Gollop N. Partially Purified Antibacterial Agent from Maggots Displays a Wide Range of Antibacterial Activity; Presented at 3rd International Conference on Biotherapy; Jerusalem, Israel. 1998.

14.Zasloff M. Antimicrobial peptides of multicellular organisms. Nature 2002; 415: 389-95.

15.Schultz GS, Sibbald RG, Falanga V, Ayello EA, Dowsett C, Harding K, et al. Wound bed preparation: a systematic approach to wound management. Wound Repair Regen. 2003; 11: 1-28.

16. Sherman RA. Maggot therapy for treating diabetic foot ulcers unresponsive to conventional therapy. Diabetes Care. 2003; 26: 446-51. 
17. Chambers L, Woodrow S, Brown AP, Harris PD, Philips D, Hall M, et al. Degradation of extracellular matrix componets by defined proteinases from the greenbottle larva Lucilia sericata used for the clinical debridement of non-healing wounds. $\mathrm{Br} \mathrm{J}$ Dermatol 2003; 148: 14-23.

18. Mumcuoglu KY. Clinical applications for maggots in wound care. Am J. Derm. 2001; 2: 219-27. 